\title{
KOPI: OTENTISITAS MATERIAL DAN GAYA HIDUP
}

\author{
Ade Ikhsan Kamil \\ Program Studi Antropologi \\ Fakultas Ilmu Sosial dan Ilmu Politik, Universitas Malikussaleh \\ Aceh-Indonesia \\ Korespondensi: ade.ikhsan.kamil@unimal.ac.id
}

\begin{abstract}
This paper aims to see the extent to which coffee is a consumable commodity that is devoid of meaning, but coffee is also seen as a material that has been commodified so as to cause different meanings for people who consume it. By using qualitative research methods, the author wants to show that how changes in coffee as a commodity can become a lifestyle that has an impact on the meaning of the coffee commodity itself as if coffee has changed itself and given meaning to itself.

Abstrak: Tulisan ini bertujuan untuk melihat sejauh mana kopi sebagai sebuah komoditas konsumsi yang hampa makna, namun kopi juga dilihat sebagai sebuah materi yang mengalami komodifikasi sehingga menimbulkan pemaknaan yang berbeda bagi orang yang mengonsumsinya. Dengan menggunakan metode penelitian kualitatif, penulis ingin menunjukkan bahwa bagaimana perubahan kopi sebagai komoditas dapat menjadi gaya hidup yang berdampak pada pemaknaan komoditas kopi itu sendiri seolah-olah kopi telah merubah dirinya sendiri dan memberikan makna terhadap dirinya.
\end{abstract}

Kata Kunci: Kopi, Otentisitas Material, Konsumsi dan Gaya Hidup 
Aceh Anthropological Journal, Vol. 3, No. 2, hlm: 129-143, Oktober 2019

\section{A. Pendahuluan}

Food is always about more than simply what fills the stomach. (Rouse and Hopkins 2004:226)

Artikel ini berangkat dari sebuah adagium yang menyebutkan bahwa Aceh merupakan 'negeri seribu kedai kopi'. Kedai kopi di Aceh khususnya di Kota Banda Aceh telah berkembang sangat pesat dengan berbagai ragam gaya dan fasilitas dan perbedaan penyajian. Begitu pula halnya dengan kebiasaan "ngopi" dalam masyarakatnya dengan intensitas minum kopi yang tinggi sampai 5 kali dalam sehari, sehingga kopi sebagai materi sangat menarik untuk dikaji. Kedai kopi bahkan telah berubah sebagai sebuah ruang sosial yang sangat eksotis. Karena kedai kopi lah yang saat ini menjadi ruang sosial determinan bagi gerak perubahan di Aceh. Sehingga saat ini dapat dikatakan bahwa kedai kopi menjadi froentier dalam pembahasan dinamika perubahan sosial-budaya di Aceh. Akibatnya, kedai kopi menjadi layar utama bagi penegakan kebijakan populis yang sedang menghangat beberapa saat ini. Hal tersebut bisa kita lihat bagaimana upaya untuk penertiban kehidupan sosial-budaya dan politik dalam arena kedai kopi.

Terkait dengan konsumsi kopi, beberapa data telah dirilis bahwa saat ini konsumsi kopi naik signifikan di seluruh belahan dunia. Bahkan ada suatu fakta yang fenomenal yang ada di masyarakat berkenaan dengan konsumsi kopi. Seperti yang telah dikatakan oleh Catherine M. Tucker $(2011,4)$ bahwa :

"Although rates of consumption fluctuate, coffee is a customary drink and an integral part of life in many societies. Worldwide, only non-commercial water, tea, and milk appear to be consumed more frequently than coffee, although ranks vary. Depending on the year, some sources rank coffee in second place after water, or carbonated beverages above coffee (Beverage Marketing Corporation 2009; Fletcher 2006; Justaboutcoffee.com 2007). Coffee's presence has become so integral to many people's lives that most continue to drink it even if prices rise or the economy slows."

Hal tersebut diatas menandakan bahwa kopi adalah suatu komoditas yang telah menjadi bagian sejarah tersendiri dalam banyak masyarakat di dunia. Begitu juga dengan masyarakat Banda Aceh, bagi penikmat, kopi menjadi cairan yang menduduki posisi kedua yang dikonsumsi setelah air putih. Saat ini kopi dan kedai kopi telah menjadi ruang sosial baru bagi sebagian besar -jika tidak bisa dikatakan seluruhnya- warga Banda Aceh. Fakta tersebut dapat dilihat dari men-jamur-nya 
kedai kopi di setiap sudut kota Banda Aceh, dan bahkan jika kita ingin menemui seseorang tanpa ingin menghubungi atau memberitahunya terlebih dahulu, maka kita hanya perlu menungggunya di kedai kopi yang sering dia datangi, maka kita pasti akan menjumpainya disana.

Kopi telah menjadi satu komoditas yang sangat sering dikonsumsi oleh warga Banda Aceh setelah makanan pokok serta rokok, bahkan ada beberapa teman yang walaupun hanya memiliki uang Rp. 5.000, mereka berani untuk ke kedai kopi dengan hanya memesan kopi pancung dan 1 batang rokok dan duduk sampai 2 atau tiga jam. Oleh karena itu, kopi dan kedai kopi bukanlah suatu komoditas konsumsi sahaja, namun lebih dari itu, kopi dan kedai kopi telah memberikan makna yang berbeda bagi masyarakat di Banda Aceh.

Kedai kopi, dimana secara awam dimaknai sebagai bentuk dan nama lain dari restoran tidak resmi atau cafe. Selain menyuguhkan kopi, teh serta makanan ringan, kedai kopi juga menjadi pusat-pusat interaksi sosial karena kedai kopi memberikan kesempatan kepada anggota-anggota sosial untuk berkumpul, berbicara, menulis, membaca, menghibur satu sama lain, membuang waktu atau malah berkencan yang dilakukan secara individu atau kelompok-kelompok kecil.

Sehingga kalau orang hanya sekedar ingin minum kopi tentu saja bisa dilakukan di rumah, lebih murah, dan bubuk-bubuk kopi enak bisa dibeli di kedai kopi, Toko Kelontong, atau jaringan pengusaha kopi olahan. Jelaslah alasan sekedar ingin kopi ini tidaklah benar. "Ngopi" di kedai kopi adalah arena yang dicari serta diinginkan. Kedai kopi tidak hanya diartikan sebagai 'pasar' yang memiliki performa untuk mendapatkan keuntungan. Tetapi ia telah menjadi arena yang dicari dan diinginkan para konsumennya dengan berbagai alasan dan faktor yang kadang tidak memiliki dasar yang kuat. Seakan-akan "Ngopi" telah menjadi simbol komunitaskomunitas di Aceh untuk hanya sekedar melakukan pembauran dan interaksi sosial.

Di dalam arena "ngopi" sudah tidak amat penting lagi atasan dan bawahan, kaya maupun miskin, bekerja maupun pengangguran, priyayi maupun rakyat biasa, bangsawan atau bukan, ulama bisa berkelakar dengan umat, tengku bisa berdebat dengan orang awam, perempuan bisa duduk bersama laki-laki dalam satu meja. Kondisi tersebut telah menjadikan kedai kopi sebagai tempat terbentuknya pola dan 
budaya konsumsi yang sekaligus telah menjadi ruang publik dengan konstruksi citra-citra yang dibangun dalam bingkai kebutuhan semu. Konstruksi citra tersebut didukung dengan media kampanye dan promosi yang terstruktur. Kedai kopi menawarkan apa saja yang dibutuhkan dan diinginkan konsumen, bukan lagi tanggung jawab pada pemenuhan kebutuhan. Konsumerisme sebagai penopang utama ideologi kapitalis dihadirkan secara terbuka dan sangat atraktif. Sehingga konsumen hanya menginginkan nilai estetis dari pelayanan yang dia nikmati.

Sebenarnya jika kita lihat sejarah dan fakta sebelum tahun 2004. Kedai kopi hanya sebagai tempat interaksi sosial bagi masyarakat aceh, khususnya laki-laki yang selalu berada di ruang-ruang publik. Namun, sekarang ini kedai kopi telah menjadi suatu identitas dan gaya hidup bagi hampir seluruh lapisan masyarakat Banda Aceh yang berasal dari berbagai usia, jenis kelamin dan latar pendidikan serta pekerjaan. Sehingga tidak dihiraukan lagi jika kedai kopi dan budaya "ngopi" telah menjadi gaya hidup masyarakat aceh.

\section{B. Metode Penelitian}

Metode yang penulis artikan disini ada 3 yaitu, tata cara pengumpulan data, tata cara analisis, dan tata cara menulis berbagai sumber data yang penulis dapatkan sehingga lahirlah sebuah representasi yang dapat disebut sebagai sebuah karya ilmiah. Secara garis besar, penulis menggunakan pengalaman yang telah penulis jalani selama tinggal di Banda Aceh dari tahun 2002 hingga saat ini. Pengalaman dari tahun ke tahun yang penulis lihat, rasakan, dan nikmati dari berbagai perubahan kondisi kedai kopi dan bagaimana penulis sendiri merasakan perubahan terhadap pemaknaan kopi dan kedai kopi menjadi data primer dari tulisan ini. Berbagai data sekunder juga melengkapi kebutuhan penulis dalam meramu semua fakta menjadi data seperti berbagai dokumen dan literatur kepustakaan serta penelurusan secara digital bagi dari sosial media, berita daring, dan dokumen lain yang berhubungan dengan kopi. Sehingga proses analisis yang penulis lakukan adalah sebuah upaya untuk refleksi seluruh pengalaman dan fakta yang penulis lihat dan penulis ubah menjadi data yang akhirnya menjadi tulisan secara keseluruhan. 
Aceh Anthropological Journal, Vol. 3, No. 2, hlm: 129-143, Oktober 2019

\section{Pembahasan}

\section{Kopi: Konsumsi Dan Gaya Hidup}

Dalam literatur sosial humaniora, gaya hidup telah menjadi studi yang berkembang pesat dan menjadi isu penting selama dasarwarsa 1980 (di Amerika) (Martin J. Lee, 1993:iv). bahkan dalam beberapa tahun terakhir ini nampaknya hal yang sama juga terjadi pada masyarakat Indonesia. Lahirnya masyarakat konsumen di Indonesia ditandai dengan menjamurnya pusat perbelanjaan semacam shopping mall, industri waktu luang, industri mode atau fesyen, industri kecantikan, industri kuliner, industri nasihat, industri gosip, real estate, apartemen, kawasan wisata, berdirinya sekolah-sekolah mahal (dengan label 'plus'), telepon seluler dan serbuan gaya hidup melalui industri iklan dan media (Idi Subandy Ibrahim, 2007 : 133).

Berkembangnya berbagai gaya hidup adalah sebagai fungsi dari diferensiasi sosial yang tercipta dari relasi konsumsi. Di dalam perubahan tersebut, konsumsi tidak lagi sekedar berkaitan dengan nilai guna dalam rangka memenuhi kebutuhan dasar, akan tetapi kini berkaitan dengan unsur-unsur simbolik untuk menandai kelas, status atau simbol sosial tertentu, hal itu berarti konsumsi mengekspresikan posisi sosial dan identitas kultural. Sehingga yang dikonsumsi tidak lagi sekadar objek, tetapi makna sosial yang tersembunyi di baliknya. Dengan kata lain, orang akan mengkonsumsi barang bukan lagi karena fungsi barang itu semata namun karena barang tersebut menjadikan si pemakai mengidentifikasikan dirinya pada suatu kelompok (Piliang, 2004:179).

Saat ini kopi sebagai komoditas primadona yang banyak dikonsumsi orang menjadi penanda bagi status sosial. Di banda aceh akhir-akhir ini, tidak semua orang memiliki dan nyaman dengan semua kedai kopi. Karena kedai kopi saat ini telah berkembang sangat pesat dengan berbagai atribut yang dilekatkan padanya. Selain pada proses penyajian, kopi telah bertransformasi menjadi penanda bagi ruang sosial bagi kelas tertentu. Sehingga tidak semua orang memiliki preferensi yang sama terhadap kedai kopi mana yang harus dikunjungi setiap hari. sehingga beberapa orang akan membedakan kedai kopi dengan kepentingan yang sedang diperjuangkan. atau dengan kata lain, kedai kopi menjadi penanda bagi bangunan jaringan sosial seseorang. 
Sehingga apa yang dikatakan oleh Kellner (1994:4) bahwa Komoditas dibeli sebagai 'gaya ekspresi dan tanda, prestise, kemewahan, kekuasaan dan sebagainya dapat dibenarkan jika melihat konteks saat ini. Artinya ketika mengkonsumsi sesuatu, termasuk kopi dan ruang (kedai kopi), orang sedang berkomunikasi banyak hal pada orang lain, termasuk kelompok mana mereka serta apa yang membedakan mereka dengan orang lain (Ritzer, 2006 : 140). Orang ingin dibedakan dalam berbagai macam lingkungan kultural. Makan dan minum di suatu tempat tertentu menjadi penting, karena ada tanggung jawab terhadap munculnya penilaian dari orang lain. Makan dan minum bukan hanya sekedar makan dan urusan perut, tetapi gaya hidup. Hal ini yang menyebabkan mengapa orang memilih Pizza Hut sebagai bagian 'budaya makan'nya, lebih memilih belanja di Sogo ketimbang di Ramayana, memilih olah raga di fitness center, mengendarai mobil BMW, memilih rumah di Kota Wisata, dsb (Piliang, 2004). Begitu juga dengan kopi, beberapa orang lebih memilih untuk 'ngopi' dengan kopi yang disajikan dengan cara yang berbeda dengan beberapa kedai kopi lain, bahkan kopi dengan tambahan unsur lainnya sudah menjadi pembeda bagaimana selera seseorang dengan selera orang lainnya. Sehingga di Aceh, seseorang sudah mulai menerima saat seseorang dinilai dari apa yang dia minum, robusta kah? Arabika kah? Atau kopi luwak? Atau kopi dengan campuran air nira? Atau bahkan saat ini sudah ada kopi dan bir pala. Dengan demikian, seseorang sekarang membeli bukan karena barang atau jasa itu sendiri tapi rangkaian kata, simbol yang membentuk gaya hidup yang disimbolisasikan dalam tanda-tanda yang dibuat. Konsumen diistilahkan sebagai "consumers are the citizen of brand". Logika konsumen adalah logika merek atau brand.

Fenomena ini sejalan dengan apa yang dikemukakan Audifax dalam tulisannya yang berjudul Gaya Hidup : Antara Alternatif dan Diferensiasi (dalam Alfathri Adlin, 2006 : 108) bahwa para pakar pemasaran, begitu menyadari hasrat manusia yang terus mencari dan mencari identitas yang membedakan dirinya dengan yang lain. Hasrat ini kemudian dieksploitasi sedemikian rupa sehingga orang mengkonsumsi pelbagai produk dan jasa untuk kemudian mengkombinasikan dalam gaya hidup dan menjadikannya identitas diri. 
Identitas diri menjadi unsur penting sebagai upaya pembentuk elemen diferensiasi sebagai salah satu strategi penting. Menjadi berbeda bisa dilakukan dengan perencanaan strategis yang memperhitungkan kelemahan pesaing. Pemasaran bukan berkaitan dengan lebih baik atau lebih buruk, melainkan sebuah perang. Meski Trout membahasnya dalam konteks bisnis pemasaran, namun perang inipun juga berlaku dalam konteks memasarkan 'diri' dalam kultur. Gaya hidup adalah bagian dari perang itu; dan ini bukan masalah lebih baik atau lebih buruk, tetapi bagaimana menjadi suatu yang berbeda dan eksis dalam perbedaan itu (Jack Trout 2004 : 69).

Lebih lanjut Audifax (dalam Alfathri Adlin 2006 :108, 111) menyatakan bahwa gaya hidup selalu berkaitan dengan upaya membuat diri eksis dalam cara tertentu dan berbeda dari kelompok lain. Disini ada suatu perilaku konsumsi dimana orang berada dalam kondisi selalu tak terpuaskan. Suatu pola konsumsi yang dibangkitkan oleh produsen, melalui pencitraan. Citra (image) menjadi bahasa komunikasi sosial di dalam masyarakat konsumen, yang di dalamnya telah diciptakan klasifikasi dan perbedaan sosial menurut kelas, status dan selera. Karena pada dasarnya orang mengkonsumsi untuk membentuk style tertentu dalam dirinya, membangun pencitraan tertentu, menggapai gaya hidup yang memapankannya dalam arus besar hal-hal yang dianggap bernilai dalam budaya masyarakatnya.

Apa yang dipaparkan di atas memperlihatkan bahwa gaya hidup bukan merupakan sesuatu yang alamiah dan terjadi dengan sendirinya, akan tetapi dikonstruksi dan direproduksi terus menerus oleh berbagai kelompok. Dengan kata lain pembentukan dan pembedaan gaya hidup yang hierarkis untuk membedakan kelas. 
Aceh Anthropological Journal, Vol. 3, No. 2, hlm: 129-143, Oktober 2019

\section{Otentisitas Materialitas Dan Komodifikasi Kopi}

Jika berbicara tentang otentisitas materialitas, maka kita tidak lepas dari objek materi yang ada di sekitar kita. Dan hal tersebut termasuk juga kopi. Suatu material yang dimaknai oleh manusia dengan beragam pemaknaan akibat dari kesepakatan ataupun kesadaran bersama selalu direpresentasikan oleh manusia sebagai sesuatu yang dapat dimiliki. Manusia memberikan batasan-batasan bagi orang lain tidak hanya dalam aturan normatif, namun juga pada suatu materi agar materi yang diberikan batasan itu dapat membedakan dirinya dengan orang lain. Oleh karena itu, kadangkala suatu materi digunakan untuk mengidentifikasikan identitas etnis, agama, negara serta strata sosial. Setiap materi yang dapat merepresentasikan suatu hal di luarnya adalah apa yang disebut dengan otentisitas materialitas. Suatu materi seakan-akan memiliki jiwa yang dapat menunjukkan hal lain di luarnya dan seakan-akan materi hidup dan berbicara ke orang lain bahwa dia adalah kepunyaan seseorang.

Karena kopi sebagai materi tidak hanya dilihat oleh manusia memiliki nilai otentisitas semata, maka sebagai mahluk biologis yang mempunyai kebutuhan untuk memenuhi kehidupan sehari-hari, manusia menggunakan materi yang ada di luarnya untuk digunakan sebagai benda yang dapat dikonsumsi dan dapat dijadikan alat memproduksi suatu barang. Oleh karena itu, bagi Marx (1978), dialektika nilai guna dan nilai tukar yang ada pada suatu benda menentukan bagaimana sejarah manusia. Artinya bahwa suatu materi atau benda di luar manusia dapat mempengaruhi bagaimana manusia melakukan sesuatu dan dapat mendeterminasi posisi, status, dan kedudukan secara politik, ideologi dan relasi gender (suprastruktur).

Kopi sebagai suatu benda tidak hadir dengan sendirinya di depan mata manusia akan tetapi kopi sebagai suatu benda atau materi adalah hasil dari kerja yang dilakukan oleh seseorang atau sekelompok orang. Oleh karena itu, untuk melihat bagaimana kopi memiliki nilai guna dan nilai tukar yang kemudian diubah menjadi komoditas yang dapat dikonsumsi melalui praktik pertukaran sebenarnya memiliki kontradiksi-kontradiksi. Oleh karena itu, untuk mengetahui bagaimana kontradiksi-kontradiksi tersebut diselesaikan kemudian diterima menjadi milik diri 
Aceh Anthropological Journal, Vol. 3, No. 2, hlm: 129-143, Oktober 2019

seseorang (subjek) maka kita harus melihat bagaimana kapitalisme klasik mengembangkan gagasannya mengenai komoditas. Dengan demikian, pada titik ini kita harus melihat pemikiran Marx (1978) dalam membedah proses pertumbuhan nilai tambah (surplus) dari sebuah komoditas (termasuk kopi di dalamnya). Marx memulai pembahasannya tentang bagaimana kapitalisme melihat suatu komoditas yang notabene merupakan hasil dari proses produksi. Oleh karena itu, dia menyatakan bahwa, kemakmuran masyarakat kapitalis adalah timbunan besar komoditi, sehingga marx mengawali telaahnya tentang kapitalisme dan proses produksinya dengan menjelaskan tentang komoditi. Marx berasumsi bahwa komoditi adalah segala sesuatu yang berada di luar diri manusia atau komoditi as a thing. Begitu juga dengan kopi sebagai suatu benda yang berada di luar dari diri manusia. Kopi akan berkembang dengan berbagai makna yang diberikan oleh manusia itu sendiri. Namun seolah-olah dia dapat berdiri sendiri dan mengatakan pada khalayak ramai bagaimana aroma kopi menjadi primadona.

Kopi sebagai benda itu sendiri memiliki dua sudut pandang, yaitu secara kualitas yang memiliki sifat unsur-unsur, dan secara kuantitas yang memiliki jumlah. Kegunaan dari sebuah benda adalah urusan sejarah, oleh karena itu setiap benda memiliki sifat hakiki yang dibawanya seperti benda dan magnit dimana sifat gunanya adalah "kutub magnit". Jika kita telisik secara sosial, maka nilai pakai suatu benda secara kuantitas tolak ukur atau kriteria yang digunakan adalah karena keragaman sifat benda sehingga benda menjadi berbeda satu sama lain, dan karena kebiasaan masyarakat yang beranggapan bahwa benda tersebut memiliki nilai pakai. Maka tidaklah mengherankan jika dilihat dari dua sudut pandang tersebut, bahwa kopi memiliki nilai kulturalnya masing-masing dari sifat unsur dan kuantitas. Bagi para eksportir, kopi Arabika khususnya yang ada di Gayo dilihat sebagai kuantitas yang menghasilkan pundi-pundi dollar, namun bagi petani yang merawat kopi, ada unsur lain yang dilighat olehnya yang membentuk dirinya dalam irama sejarah yang sama. Hal tersebut bisa dilihat dari bagaimana syair kopi yang masih hidup dalam relung kehidupan petani gayo yang menandai bahwa kopi sebagai sesuatu yang hidup. 
Oleh karena itu, kopi akan menjadi komoditas saat kopi dilihat sebagai benda yang memiliki nilai guna dijadikan sebagai komoditas yang memiliki nilai tukar yang nilai tukar tersebut kemudian memunculkan pengertian yang kontradiktif. Dengan demikian, dampak moral yang terjadi akibat dari pemahaman manusia terhadap komoditas pada waktu itu hanya sebatas menjadikan komoditas sebagai obyek yang dikonsumsi saja. Sehingga tidak melahirkan etika-etika baru dalam praktek konsumsi dan hanya melahirkan perjuangan / resistensi kelas terhadap struktur yang dominan akibat dari eksploitasi kerja dan akumulasi kapital.

Apa yang penulis sampaikan diatas, adalah apa yang disebut Marx (1978) sebagai asal mula sejarah manusia yaitu sejarah perjuangan kelas. Namun pada tulisan ini, penulis tidak membahas tentang sejarah perjuangan kelas, akan tetapi lebih memfokuskan pembahasan pada dampak moralitas yang terjadi akibat dari perubahan otentisitas materialitas yang dikomodifikasi oleh kapitalisme global akibat dari terbukanya batas-batas dunia karena globalisasi.

Perubahan material yang memiliki representasi seakan-akan memiliki pemilik ke komodifikasi itu ditenggarai atau dijembantani oleh adanya ideologi pasar bebas yang berkembang karena pengaruh globalisasi ekonomi. Soros (1998:167-168) menyatakan (dalam Margaretha) bahwa globalisasi ekonomi diartikan sebagai lalu lintas barang dan modal secara internasional. Artinya bahwa suatu barang tidak memiliki awal dan akhir yang nampak dari suatu produk, barang dan modal dapat hadir dimana saja dan berpindah kemana saja karena kepentingan akumulasi kapital. Komodifikasi adalah suatu proses menjadikan benda yang sebenarnya memiliki nilai guna saja diubah menjadi memiliki nilai tukar (berlebihan). Komodifikasi suatu benda atau material itu akibat dari kepentingan kapitalisme global dalam membuka pasar sebesar-besarnya agar adanya keseimbangan antara produksi dan konsumsi supaya pasar tetap stabil dan tidak terjadinya penurunan keuntungan dari industri kapitalisme.

Dampak yang terjadi akibat dari fenomena tersebut adalah suatu hal yang niscaya. Karena suatu perubahan pasti terjadi karena hubungan-hubungan dialektis antara manusia dengan benda / material di sekitarnya. Penulis akan menjelaskan beberapa dampak yang terjadi akibat dari perubahan cara pandang terhadap suatu 
materi yang ada di sekitar manusia. Perubahan tersebut salah satunya adalah menghilangkan esensi dari suatu produk, bahwa suatu produk industri merupakan hasil kerja keras dari para pekerja yang sudah "berdarah-darah" dalam bekerja membuat suatu produk dari bahan mentah yang tidak pernah dipikirkan oleh para konsumen. Di depan mata konsumen, produk industri terlihat seperti ada dengan sendirinya dengan berbagai keindahan dan kemewahan tampilan, dan itu yang dimaksud dengan fetishisme komoditi. Akibat dari fetisisme komoditi, maka para konsumen telah memiliki kesadaran-kesadaran yang sengaja dibentuk oleh kapitalisme global bahwa produk-produk tersebut merupakan pemuas kebutuhan manusia yang tidak memiliki nilai sejarah baik dari segi produksi dan relasi produksi. Akibat dari hal itu, terjadi berbagai perlawanan atau perjuangan. Salah satunya adalah perjuangan kelas dari kaum yang merasa tertindas atas dominasi elit kapitalis. Dan itu yang disebut oleh marx sebagai kesadaran palsu (false counciousness). Yaitu kesadaran yang sengaja dibentuk oleh aktor tertentu karena hubungan dialektis yang terjadi dengan benda material di sekitarnya. Dan kesadaran tersebut ada karena sharing pengalaman, merasa memiliki emosi yang sama dan tujuan perjuangan yang sama.

Ada dua bentuk false counciosness yang penulis lihat, yaitu etika konsumerisme serta budaya konsumerisme. Etika konsumerisme lahir dari adanya gerakan fair trade akibat dari merajalelanya kapitalis dalam mendominasi suatu produk khususnya produk dari negara-negara utara. Sedangkan budaya konsumerisme lahir dari adanya konsumsi simbol dan tatanan tanda yang berlebihan yang bertujuan untuk diferensiasi sosial antara konsumen. Keduaduanya penulis kategorikan dalam kesadaran palsu yang sengaja dibentuk oleh kapitalisme global. Dan keduanya kadang dipikirkan sebagai dua hal yang berbeda yang terjadi akibat dari adanya ideologi pasar bebas. Namun, menurut penulis hal itu adalah seperti lingkaran setan yang para konsumen berada pada suatu ruang yang tak pernah menyelesaikan persoalan sesungguhnya. Oleh karena itu, kesadaran yang terbentuk tersebut merupakan dampak yang riil karena adanya permainan kapitalisme global dalam membuka pasar baru untuk menciptakan suatu ekuilibrium bagi eksisnya industri kapitalisme global. 
Dengan demikian, dampak moralitas yang terjadi akibat dari terbentuknya kesadaran palsu berupa etika konsumerisme dan budaya konsumerisme adalah bahwa masyarakat cenderung menjadi individualis pada satu sisi. Dan menjadi sangat ber-solidaritas pada sisi yang lainnya. Konsumsi tanda dan simbol hanya membuat konsumen jauh dari esensi suatu produk dan nilai sosial yang dimiliki oleh suatu produk. Sedangkan etika konsumerisme itu hanyalah pemaksaan kepada para konsumen dalam menyelesaikan masalah yang tidak pernah mereka lakukan sebelumnya. Persoalan kapitalisme global dengan ideologi pasar bebas dibebankan kepada konsumen, bukan menyelesaikan persoalan pada sistem kapitalisme itu sendiri. Konsumen hanya jadi sapi perahan yang diberikan "kebebasan" memilih, padahal pilihannya itu hanya kesadaran palsu.

\section{“Ngopi”, Konsumsi Ke Lifestyle}

Dengan meningkatnya pembukaan warung kopi baru di Banda Aceh dalam beberapa tahun terakhir ini, maka pertumbuhan yang signifikan tersebut menyebabkan perubahan yang signifikan juga terhadap pola hidup masyarakat di Banda Aceh. Telah dijelaskan di atas bahwa "tradisi ngopi” bagi masyarakat Banda Aceh dimaknai sebagai warisan dari nenek moyang, karena dahulu relasi sosial masyarakat Aceh, khususnya laki-laki, selalu berada pada ruang publik dan sangat jarang berada pada ruang-ruang domestik. Oleh karena itu, relasi sosial yang dibentuk dengan memanfaatkan material kopi dalam kebiasaan "ngopi" sebagai suatu ritus yang dilaksanakan secara periodik yang membentuk nilai-nilai baru seperti terbentuknya solidaritas yang kuat antara mereka.

Kopi sebagai konsumsi merupakan suatu hal yang biasa dan wajar dalam kehidupan manusia. Karena manusia pasti akan selalu melihat suatu benda dari sisi nilai guna dan nilai tukar. Oleh karena itu, kopi sebagai suatu komoditas menjadi alasan bagi para pengusaha kopi dalam memulai usahanya karena yang pertama kopi sebagai komoditas yang dapat dikonsumsi, dan kopi sebagai komoditas yang memiliki sejarah yang panjang di Aceh. Perubahan konsumsi menjadi suatu gaya hidup baru bukanlah suatu hal yang mustahil. Apalagi jika suatu komoditas yang memiliki sejarah yang panjang serta ditopang oleh berbagai informasi dari iklan bahwa konsumsi kopi dapat menyebabkan tubuh menjadi sehat, serta kopi dapat 
membangun suatu solidaritas. Oleh karena itu, sebagai suatu komoditas yang telah dikomodifikasi oleh para pengusaha lokal, maka perubahan gaya hidup adalah suatu hal yang niscaya.

Diantara dampak yang terjadi akibat dari pertumbuhan ngopi di masyarakat Banda Aceh adalah :

1. "ngopi" telah menjadi suatu gaya hidup baru "life style" bagi para penikmat kopi. Hal tersebut dapat dilihat dari kuantitas konsumsi kopi perhari, adanya pemilihan tempat untuk menikmati kopi (tempat menjadi tanda yang dikonsumsi), konsumen yang mengkonsumsi kopi lintas profesi, gender dan umur.

2. Warung kopi telah menjadi satu ruang kultur baru bagi masyarakat Banda Aceh. Ruang kultur disini dimaknai sebagai ruang terjadinya relasi sosial antara individu yang saling berbagi informasi dengan sesama. Serta warung kopi dapat dikatakan sebagai ruang kontestasi identitas bagi setiap orang yang mengkonsumsi kopi.

3. Adanya diferensiasi sosial antara para konsumen kopi. Diferensiasi sosial tersebut terjadi akibat dari kontestasi identitas antara para penikmat kopi di suatu warung kopi. Sehingga stratifikasi sosial sangat kentara terlihat dari satu meja dengan meja lainnya. Walaupun warung kopi dapat dimaknai sebagai suatu proses liminoid. Namun dalam proses perkembangannya, setiap komunitas akan mengembangkan nilainya masing-masing sehingga menjadi struktur baru dalam komunitas yang berbeda-beda.

\section{Kesimpulan}

Sebagai suatu kawasan dengan banyak tradisi dalam kehidupan sosial masyarakat Banda Aceh. Kopi telah menjadi satu komoditas yang selalu ada dalam kegiatan lintas tradisi dan acara seremonial lainnya. Ketika seseorang yang berada dalam ruang-ruang tertentu dan mengutamakan solidaritas sosial sebagai nilai yang menghubungkan diantara mereka, kopi acapkali menjadi satu minuman yang menjadi hidangan pembuka walaupun penulis tidak mengecualikan teh, namun kopi tidak akan menjadi pilihan jika memang orang tersebut tidak bisa lagi mengkonsumsi kopi karena alasan kesehatan. 
Karena kopi memiliki nilai sejarah yang panjang di dunia, dan bahkan bagi warga di Banda Aceh. Maka kopi seakan-akan telah menjadi suatu tradisi yang dimaknai adalah peninggalan nenek moyang. Padahal jika kita menelisik sejarah, kopi sebagai komoditas adalah komoditas yang diperkenalkan oleh kolonial Belanda dengan tujuan akumulasi kapital. Namun, sebagai seorang manusia, warga Banda Aceh memberi makna yang berbeda terhadap kopi. Seakan-akan kopi adalah milik mereka dan merepresentasikan identitas etnis yang bertujuan untuk menunjukkan suatu sejarah perlawanan terhadap penjajahan dahulu kala.

Namun, lamban laun konsumsi terhadap kopi telah dikomodifikasi oleh para pemilik modal di Banda Aceh. Kopi telah menjadi satu komoditas utama dalam kegiatan wirausaha di Banda Aceh. Oleh karena itu, pembukaan kedai kopi sebagai pilihan pertama untuk berwirausaha pasti ada dalam setiap benak pengusaha yang sudah berpengalaman ataupun pengusaha pemula. Berbagai usaha kedai kopi dibangun dengan berbagai corak yang merepresentasikan suatu usaha berskala modern dengan memanfaatkan komoditas yang sudah sudah dianggap sebagai warisan nenek moyang. Oleh karena itu, seiring waktu berjalan, kedai kopi telah menjadi suatu arena kultural baru bagi warga Banda Aceh. Apalagi setelah terjadinya berbagai momentum penting, seperti proses rehabilitasi dan rekonstruksi pasca bencana gempa dan tsunami serta penandatanganan MoU Helsinki yang membuat Banda Aceh menjadi suatu daerah yang kondusif untuk peluang usaha dengan asumsi bahwa daya beli masyarakat semakin tinggi.

Karena hal tersebut, bukanlah hal yang mengherankan jika konsumsi kopi yang mulai dimaknai sebagai suatu tradisi berkembang dan bertransformasi menjadi suatu gaya hidup baru. Hal tersebut terjadi akibat dari pemaknaan yang berlebihan terhadap kopi dan kedai kopi yang bagi mereka bisa membuat status dan kelas mereka menjadi berbeda.

\section{Daftar Pustaka}


Audifax. 2006. Gaya Hidup : Antara Alternatif dan Diferensiasi (dalam Alfathri Adlin (editor) Resistensi Gaya Hidup : Teori dan Realitas. Yogyakarta : Jalasutra

Baudrillard, Jean. 2009. Masyarakat Konsumsi. Yogyakarta. Kreasi Wacana.

Featherstone, Mike. 2008. Posmodernisme dan Budaya Konsumen. Yogyakarta. Pustaka Pelajar.

Ibrahim, Idi Subandy. 2004. Lifestyle Ecstasy, Kebudayaan Pop Dalam Masyarakat Komoditas Indonesia. Yogyakarta : Jalasutra

Kellner, Douglas. 1995. Media Culture. Cultural Studies, Identity and politics between the modern and the postmodern. London-New York : Routledge.

Lee, Martin J. 1993. Consumer Culture Reborn, The Cultural Politics of Consumption. London-New York : RoutledgeLareau, Annette and Dalton Conley, eds. 2008. Social class: how does it work? New York: Russell Sage Foundation.

Margaretha Kushendrawati, Selu. 2006. Masyarakat Konsumen Sebagai Ciptaan Kapitalisme Global: Fenomena Budaya dalam Realitas Sosial. Makara Sosial Humaniora. Vol 10. No. 2. Pp.49-57

Maria Sigurdardotir, Hilda, Coffee, The Drink of Choice,http://ezinearticles.com

Marx, Karl. 1978. Kapital I, Seri Buku Ilmiah. Pelican Books. London.

Retnandari N.D. dan Moeljarto Tjokrowinoto. 1991. Kopi, Kajian Sosial-Ekonomi. Yogyakarta. Aditya Media.

Ritzer, G. 2011. Globalization The Essentials. United Kingdom. John Wiley \& Sons Ltd.

Tucker, Catherine M. 2011. Coffee Culture ; Local Experience, Global Connection. Madison Avenue. New York : Routledge.

Yasraf Amir Piliang. 2006. 'Imagologi dan Gaya Hidup : Membingkai Tanda dan Dunia' Dalam Alfathri Adlin (editor) Resistensi Gaya Hidup : Teori dan Realitas. Yogyakarta : Jalasutra 